\title{
Self-build communities: the rationale and experiences of group-build (Baugruppen) housing development in Germany.
}

\author{
Iqbal Hamiduddin ${ }^{1}$ and Nick Gallent ${ }^{2}$ \\ 1Bartlett School of Planning (UCL), i.hamiduddin@ucl.ac.uk \\ 2Bartlett School of Planning (UCL), n.gallent@ucl.ac.uk
}

\begin{abstract}
Group-build housing developments can bring together the cost and customisation benefits regularly attributed to self-build housing with a communitarian ethos associated with 'intentional' communities. This paper presents an initial examination of the rationale, motivations and social experiences of group-build housing from Germany, where over half of all new homes are produced independently from volume-build developers. The paper aims, firstly, to test the hypothesis that group-build delivers general 'community' benefits; secondly, to contribute to an understanding of the processes leading to successful schemes; and lastly, to demonstrate that by making individual home-building dependent on the success of a larger group, collective interests can prevail over personal pursuit. This research draws attention to the motivations, the social experiences through the development process, and the social legacy - aspects of particular interest for policy makers as well as prospective builders - of group-build housing projects.
\end{abstract}

Keywords: Group-build, Housing, Community

\section{Introduction}

Although speculative volume building has become dominant in many housing markets internationally, there are still countries in which individually-commissioned or self-built housing remains the rule rather than the exception. Within Europe, the extremes of volume and selfbuild delivery are commonly illustrated by the case of the UK on the one hand (where more than $80 \%$ of housing is developer-built in a market dominated by a small number of large volume builders) and Germany on the other (where over $60 \%$ of housing is delivered to individual households by small local builders) (Lloyd et al, 2015; Duncan and Rowe, 1993). Germany is not unique. Austria and Switzerland, for example, display a similar housing market profile, showing that the speculative development of housing by a few dominant companies is not an inevitable outcome or signal or economic advancement. Germany's housing market has a number of features which have attracted international interest. First amongst these is the dominance of individual custom or self-build housing production within a housing market that continues, for reasons explored later, to be characterized by low rates of home ownership and high levels of long-term market renting (Voigtländer, 2009; Golland, 1996). These features hint at the peculiarity of the German market and act as a warning to those who would seek to transfer simple lessons from Germany to other European countries. A second point of general interest has been the conspicuous level of experimentation and innovation in 'sustainable' urbanism, and particularly the emergence of an 'intelligent trial and error' (ITE) approach (Dotson, 2015) linking novel means of housing production to innovative residential design. One particularly striking aspect has been the physical scale of some ITE projects in Germany, including the 2,500home Vauban car-free suburb in Freiburg, Tübingen's 2,700-home French Quarter and the 6,000-home HafenCity mixed-use quarter that is currently under construction in Hamburg. Elsewhere, projects of this type - that experiment with new forms of urbanism and housing production - have been far more modest in scale and include Edinburgh's 120-home Slateford Green car-free development, South London's 88-home BedZed low-energy scheme and Bristol's 48-home Ashley Vale community-build project (Hamiduddin, 2015).

Community-led development - and particularly group-build - has been centrally important in the roll-out of ITE schemes across Germany (Tummers, 2015; Dotson, 2015) with the aim being to deliver places with particular social as well as physical qualities. Although the use of group-build 
or Baugruppen development approaches has been described as a 'revival' of an older tradition of Genossenschaften (Tummers et al, 2015: 72), it is distinctive in that it moves beyond simple cooperative ownership of buildings. Group-build offers a broader response to three key dilemmas in housing policy. Firstly, it responds to the issue of housing affordability, partly because of the cost savings that derive from self-build compared with speculative production (Lloyd et al, 2015) and partly because of the economies of scale that collective schemes deliver relative to individual selfbuild projects (Hamiduddin and Daseking, 2014). Secondly, there is scope for the development process to deliver higher levels of sustained social interaction, eventually leading to more cohesive communities as evidenced by higher levels of communication and strengthened social ties between residents (ibid.). And thirdly, group-build offers a distinctive approach to housing development that is mirrored by the diversity and distinctive qualities of housing produced, with homes more closely matched with the needs of occupant households.

Of these three key dilemmas in housing policy - and potential benefits derived from group-build - this paper focuses on the social outcomes of the group-build development process. Through semi-structured interviews undertaken with members of two group-build housing schemes in the German cities of Freiburg and Cologne (and development professionals in these cities) the paper examines resident motivations for embarking on this particular approach to housing development. More particularly, it considers whether interactions during the project management and build processes are sustained and deliver a lasting social legacy.

\subsection{Housing in Germany}

Germany's housing market has long been characterized by low levels of home ownership in comparison with international standards. A home ownership rate of $43 \%$ contrasts with rates of above $70 \%$ in Spain and the UK (Voigtländer, 2009). Moreover, this headline rate varies greatly from place to place, reaching its lowest level of under $25 \%$ in the largest metropolitan areas including Berlin and Hamburg and its highest, of above 50\%, in more rural regions such as Saarland and Baden-Württemberg (Westerheide, 2012). There are also higher rates of home ownership amongst older households (in the 65 to 80 cohort) while younger households (headed by someone under the age of 50) are increasingly less likely to be home owners (Westerheide, 2012). Voigtländer (2009) attributes these German patterns to five key factors: (1) the relative size and quality of the rental and owner-occupied segments of the housing market; (2) the tax treatment of owner-occupied homes; (3) mortgage lending criteria and the terms of mortgage finance; (4) the relative cost of owned and rented units; and because of these factors (5) the reduced investment appeal of German homes (Boehm and Schlottmann, 2014). The current structure of the German housing market, and specifically the high proportion of private renting, is a consequence of the post-war response to an acute housing shortage after 1945. Roughly one-fifth of the nation's housing stock was destroyed during the war and another fifth was severely damaged. Federal housing laws enacted in 1950 and 1956 encouraged privatelyorganized development for rent through the payment of state subsidies on schemes compliant with minimum standards on space and fittings. The policy halved the housing shortage between 1950 and 1956 and led directly to the market structure observed today (Voigtländer, 2009; Westerheide, 2012).

It was not until the emergence of mortgage products in the 1960s that private house-building for owner-occupation began to exceed the output of new homes for the rental market. Yet even today, a combination of lower loan-to-value (LTV) rates typically in the region of $60-65 \%$, relatively high long-term fixed interest rates and an 'un-dynamic' property market - that was severely depressed for over a decade following the reunification of East and West Germany in 1991 - means that home ownership has remained a generally less attractive tenure than in comparable industrialised nations (Bentzien et al, 2012).

\subsection{Self-provided housing in Germany}

In Germany today, more than $60 \%$ of new property built for private ownership comprises 
individually-commissioned self- or custom-build development (i.e. 'self-provided housing') delivered by smaller regional developers (Duncan and Rowe, 1993). However, new owneroccupied development may be constrained by municipal controls on land supply for private ownership, where municipalities are required to bear the costs of new infrastructure to service new housing (Ball, 2005). At the margin of traditional private owner-occupied housing, housing cooperatives are estimated to deliver 15 to $17 \%$ of housing across Germany (Tummers, 2015) and it is into this sector that group-build or Baugruppen housing schemes have been placed. Indeed, Tummers (2015: 72) argues that:

[...] the younger generations in Germany have revived the tradition of Genossenschaften nowadays in Baugruppen, which implies a shift in the economic/cultural background of residents involved $[\ldots]$ and creates new overtures in urban development policies relying on self-development.

As well as associating Baugruppen with the mutual cooperative model, Tummers (2015) also draws a parallel with the 'intentional' community ambition of co-housing and its emphasis on shared facilities and communal living. Although such comparisons have some merit, with some schemes tending towards co-housing for example in the practical provision of shared facilities or prior motivations of residents, the Baugruppen model remains distinctive. A common house or centre - a critical social and physical focal point of co-housing (Sargisson, 2012) - can seldom be found, and the schemes rarely adopt the model of mutual or cooperative ownership that characterises Genossenschaften projects. Although a group may intend to live together as neighbours, their goal is to do so as private owners of separate properties.

The self-provided sector embraces a number of different models, of which group self-build is just one. Key cities - including Freiburg, Berlin, Tübingen and Hamburg - have become strongly identified with experiments in group self-build. This is because these cities have experienced sustained population growth, which has altered their demographic and generated intense pressure at the entry-level of their housing markets. Droste (2015: 81) argues that

[...] self-organised and community-oriented housing has often gained importance in times of social change and, like recently, economic crisis [...]. The recent unexpected increase in demand for lower-priced quality housing in growth areas across Germany has forced municipalities, public and non-speculative housing providers to re-consider the best use of new and existing stock.

In relation to Freiburg and Tübingen, Tummers (2015: 73) draws attention to the ways in which group self-build has been promoted as a new orthodoxy in housing delivery:

Since the 1990s, these towns have adopted planning strategies for new housing areas that are based on collective self-development by inhabitants. Both the substance of planning, such as the size of plots in the Masterplan, and the process of planning, supporting the formation and development of Baugruppen, have been transformed over the years to embed the strategies in a structural way.

In Freiburg, the city administration provided serviced self-build plots for Baugruppen on sites across the city (Hall, 2014), enabling over 1,100 homes to be delivered in the two decades between 1993 and 2013 (Hamiduddin and Daseking, 2014). Public control of land (but not necessarily direct ownership) has been a key enabling factor with, the municipality able to exercise a high level of control over planning permission and the freezing of land prices through powers similar to compulsory purchase orders (CPO) in the UK. Plots have been disposed of at a fixed price, with infrastructure overheads internalised. At Vauban and Rieselfeld (neighbourhoods in Freiburg), price freezing and disposal have been a crucial means of valuecapture, delivering significant funds for the extension of Freiburg's tram network (which has itself been crucial to the success of new residential quarters). The quality of development proposals was given equal importance to price in the bidding process for plots. Design 
competitions were used to select successful bids. Also at Vauban and Rieselfeld, a relaxation of the city-wide design framework was intended give groups scope for personal expression and to deliver variety through the 'intelligent trial and error' (ITE) approach which, in the case of the Südstadt southern fringe urban extension in Tübingen, sought to produce greater porosity between buildings and adjacent streets and public spaces.

In both of these cities, the delivery of more affordable housing has been a primary goal of municipal support for group-build. These are small university cities in the attractive Black Forest region of South West Germany. Many students remain in the cities after graduation, fueling demand for housing. Although the communitarian aspect of group self-build does not seem to have been a key policy motivation of either municipality, it is likely to be a contextual factor that explains some of the popularity of this model in these particular locations. Groups in Vauban actively lobbied against developer-led housing in the new quarter (Hamiduddin and Daseking, 2014), arguing instead for greater community involvement in shaping these new urban spaces.

Such involvement is often presented as, or assumed to be, the path towards a more inclusive process. However, this community development aspect of group-build (i.e. development of the community by the community) has been flagged up as problematic by some researchers. Hamiduddin (2015), for example, has argued that empowering communities to play a more active part in the development process may have an exclusionary effect as groups coalesce in a selfselective way and de-select those who do not appear to fit the group-build mould; indeed, groupbuild may favour the young and the affluent, and those about to start a family. Droste (2015: 81) identifies group-builders as middle-class pro-active gentrifiers. In Freiburg, the sometimes narrow socio-demographic mix resulting from group-build has become a cause of concern, highlighting the problem of residential exclusion, which even community-based solutions can promote.

\section{Motivations for and benefits of group-build housing}

Before moving to the central question of this paper - whether a social legacy results from groupbuild - it is perhaps worth looking across the presumed motivations for, and benefits of, this form of housing production. Brown et al (2013) have drawn attention to what they view as the core considerations amongst self-builders: deriving benefits in terms of reduced cost and greater potential for customisation, matched to personal needs and preferences. Drawing on the work of Cerulli and Field (2011), they add to these two considerations the promise of creating liveable communities', rooted in the social interactions that were crucial to the success of this form of group-based, non-speculative, production.

\subsection{Financial Considerations (Cost)}

Affordability looms large in home-procurement decision-making and there is substantial evidence to suggest that the cost of self-build compares favourably with developer-built housing (NaSBA, 2011 and 2012). Wallace et al (2013) cite a recent survey among British self-builders, noting that half believed that self-build offers significant financial benefits. Cost-savings (and the possibility of spreading costs over a longer period) create the opportunity to develop higher-spec homes with the same or a smaller budget. In a study of six self-build projects in southern England, Brown (2007: 273) observed that

[...] the value of self-building was less about immediate financial return, and far more about the ability to acquire property of greater value as a consequence of the self-build process (that can take place over a long period of time drawing upon income rather than savings $[\ldots]$ and through the contribution of labour in exchange for a lower purchase price).

In Brown's study, self-build was the only affordable means of housing access for some families in an expensive region, while Barlow et al (2001) adds that, historically, self-build in the UK has also 
been used as a last resort option for those unable to enter the housing market by other routes. Because of economies of scale in the build process, group-build (as opposed to individual selfbuild) seems to accentuate the affordability benefit, with households typically saving upwards of 20\% over individual self-build housing (Hamiduddin and Daseking, 2014).

\subsection{Identity and Place (Customisation)}

A second potential motivation for group-build is to garner a sense of collective identity and belonging. Clapham (2005) argues that when people aspire to have a home of their own, they are seeking more than a roof over their head. A home provides a great deal more than a physical space but rather provides '[...] one of the greatest powers of integration for the thoughts, memories and dreams of mankind' (Bachelard, 1994: 6). It is a social space for both private and collective dwelling (King, 2004) and the basis for belonging to a particular place (Savage et al, 2005) and community. Bachelard (1994: 4) asserts that '[...] our house is our corner of the world [...] a real cosmos in every sense of the word'. The same 'anthropocosmic' sentiment emerges from Heidegger's (1971) conception of 'dwelling' in which the domestication of space is viewed as the 'essence of being' (p. 148). Brown (2007: 264) explicitly connects Heidegger's notion of dwelling to self-build housing, arguing that it represents - as process and product - a ' $[\ldots]$ continuity of lived experience on the one hand $[\ldots]$ and a representation of the social world on the other'. It is an act of domestication that places the eventual occupant of a home centre-stage, generating identity and attachment. Spaces are created that are closely aligned to individuals' needs, aspirations and ideals. Moreover, self-build is a reflexive process through which individuals better understand the needs and constraints of their physical environment (Brown, 2007; Marcus, 2006). Group-build projects extend this 'person-place' relationship (Marcus, 2006) and, because of the inter-dependencies that play a crucial part in this particular act of domestication, produce a broader social outcome, creating home from a collection of houses (Lawrence, 1987).

\subsection{Social Development (Communitarianism)}

There is clearly a strong link between the act of production and the communitarian spirit that can be claimed as an outcome of group-build. Homes collectively create the setting for the interactions through which communities are constituted. But as well as needing the product, communities also benefit greatly from being part of the process (labeled the 'act of domestication' above). Collaborative development approaches can be viewed not only as an alternative production model, driven by individual goals such as achieving cost savings, the satisfaction derived from applying (or acquiring) practical skills (i.e. the 'DIY' factor) or the desire for a bespoke home tailored to individual needs (Brown, 2007), but also as a communitarian project that brings communities together in the development process and, in doing so, helps foster social cohesion. Arguably, attempts to seed and direct community action (support for group-build being a prime example) signals a communitarian worldview, which emphasises the importance of community and the value of particular 'social goods' that arise from the interactions that constitute community life:

The starting point for communitarian theory is the basic tenet that the existence of strong community life - expressed as a state of affairs in which individuals belong to and participate in a wider group (or groups) of common interests and shared goals - is of inherent value in human society (Sage, 2012: 267)

It is through community life that collective actions are born and these actions are, in turn, central to the ongoing production of community: people coalesce around a common purpose, experience a strengthening of inter-personal bonds, pool resources, and develop a capacity to deliver an array of social goods. The fundamental social good here is the transformation of individual human capital into a collective social capital (see Chaskin et al, 2001 or Falk and Kilpatrick, 2000), or through strong relationships, the capacity to deliver against collective needs or the needs of vulnerable individuals. This thinking is rooted in ideas of community. Although 
it has been suggested that socio-spatial communities are often inert, lacking common purpose and any reason to interact (Bell and Newby, 1976), context - and in this case the goal of resolving shared housing needs - may create that purpose.

The success of group-build projects is dependent on the kinds of 'reciprocities (Weber, 1956) that underpin a sense of community. These projects can therefore be viewed as one of the many contextual opportunities that, when grasped, will advance community development. But it can also be seen as an especially significant opportunity, generating shared-purpose during its projectphase (as individuals come together around a group action) and then providing a community with a physical basis for its continued development into the future. Housing production processes, and housing (or homes) as an outcome, are important social goods. Following this line of argument, group-build provides a route to greater social cohesion and a sense of place that may be weakened where there is greater distance between housing production and consumption, and where influence over the 'domestication of space' is limited (at best) to indirect influence over incremental planning decisions. A sense of control, and being able to directly shape outcomes, seems to deliver a clearer sense of belonging (Parvin et al, 2011).

However, the link between group-build and community building is perhaps a little too convenient. Theories of 'social capital' (or the resource potential of relationships between individuals with their separate human capital) - which have gained traction in recent years - point to the limitations of community life as a source of social goods. Putnam (2000), drawing a distinction between close ties shared by neighbours (delivering bonding social capital) and links to others outside a socio-spatial community (bridging social capital), suggests that groups often lack the skills and resources needed to take on complex projects or deliver really big, important social goods. For group-build, this might mean that some places lack the requisite resources; or it might mean that groups need to look outside themselves for the skills needed to advance projects. The idea that communities have a 'store' of social capital (that may be inadequate) provides a means of understanding the close or extended reciprocities and relationships that may need to develop for projects to get off the ground: they are not an automatic or natural outcome of community life. Rather, something instrumental may need to happen for particular things to be achieved. This leads on to the concept of 'intentional communities' (Sargisson, 2012), which form and consciously self-select with a 'specific purpose in mind', drawing in the skills they need to deliver against a set agenda. They are carved from a larger society (ibid, 6) and comprise individuals who wish to live in different ways. Drawing on a study of co-housing schemes in the US, Sargisson (2012: 50) concluded that co-housing participants had 'chosen to live in a community and share goals', prefixing those communities as 'intentional'. The communitarian ideal, progressed through the resource potential of human relationships, but with a self-selecting and intentional community quality, seems to be a good descriptor of the social driver of groupbuild.

\subsection{Moving Forward}

But to what extent does this descriptor hold true; can group-build housing serve as a pathway for enhanced and sustained social relations? This question frames our analysis of group-build housing from this point onwards. Collaborative group-build projects can be examined through the lens of social capital, being characterised by two broad approaches: one which is independent and internalised within a community (reliant on bonding capital), and another which is externalised and supported by introduced expertise (that is, bridged). The suggestion is not that a deficit of social capital exists within existing, industrially-produced housing areas, but rather that collaborative-production delivers an additional opportunity for building social relations through the development process. This rationale is perhaps the least developed of the three drivers of group-build précised above. Analysis from two case studies, described below, was structured around three themes: (1) the motivations and rationales underpinning group build; (2) the experience (social and technical) of the build process; and (3) the lasting social legacy. The following critical questions are asked: 
a) Beyond the initial triggers for group-build, how do social networks act as an incubator for these schemes, and what social processes carry them forward?

b) How are schemes taken forward into the build-phase, and how important are social processes in determining outcomes?

c) What is the lasting social legacy of group-build; is there evidence of enhanced community development over conventional developer-produced housing?

d) Can group-build schemes be considered 'intentional communities?

\section{Research Approach and Findings}

This is the first investigation into the social experiences and potential learning points offered by the German group-build development approach within the academic literature. Material has been gathered from two case-study sites. The first was Vauban in Freiburg, where one-to-one semi-structured interviews were conducted with a range of different actors involved in the groupbuild development process including; Freiburg's former director of planning who was instrumental in setting the context for plot-based group-build, two architects who were involved in designing, organising and project-managing more than twenty of Vauban's group-build schemes (and over 200 in total across Freiburg and elsewhere in Germany), and a resident member of a 6-home Baugruppen scheme, as shown in Figure 1. The second site was the 16-home Sülzer Freunde project in the south-west of Cologne. Data collection in that case took the form of a single focus group with five residents. Short profiles of each scheme are provided below.

A pro-forma of common questions provided the basis for all of the 30- to 120-minute interviews, each of which was recorded and later transcribed. A thematic analysis was then undertaken in order to address the four critical research questions.

\subsection{Vauban, Freiburg}

More than 1,100 homes have been completed across the southern German city of Freiburg, of which 500 homes are located on the Vauban suburb. Named after a Napoleonic general, the site was formerly a French military barracks until the withdrawal of troops after German reunification. Control of the barracks then reverted back to the German state. Thereafter, the City of Freiburg acquired the site for a nominal fee and, after the development of a master-plan, set about disposing of plots through a competitive bidding process. A full overview of that process is provided by Hamiduddin and Daseking (2014).

[Insert Figure 1]

\subsection{Sülzer Freunde, Cologne}

Located in Cologne's Suilz district, this is a small scheme compared with the Vauban development. It is, however, a typical way of facilitating group-build on small urban infill sites. Similar schemes exist in Bremen and Hannover. Thirty five homes have been built by four separate groups on a third of a 6ha former orphanage site; each of the groups entered into a competitive bidding process in order to acquire their plots. Further details can be found at NaSBA (2014).

[Insert Figure 2]

\section{The Social Experiences of Group Build}

\subsection{Triggers and the incubating effect of social networks}

According to Freiburg's former Director of Planning, group-builders come together in one of two ways. Sometimes a pre-existing group of friends simply decides that the group-build route will deliver a desired and preferred housing outcome. The formation process might be described 
as 'organic'; it is certainly not facilitated by any external influence. The project that ensues is 'incubated' within existing social and friendship networks and it is the desire to maintain and strengthen that network which provides the primary 'social' driver for group-build, though the prospect of reduced housing costs is also crucially important. The Sülzer Freunde group claimed this social driver was key and provided ' $70 \%$ ' of the rationale. It grew from a previous experience of living in close proximity and was seen as a means of maintaining a sense of community:

We've had a kind of a community in our last apartment [block] as well and our best friends live there and they are in this group now as well, so when they came up with the project, it was absolutely clear that we were going to join it and apply for it (Female resident, Sülz̧er Freunde).

Even where practical considerations were thought to outweigh social ones, the importance of friendships in driving and incubating the process in its early stages was clear:

I think the main two motivations were the desperate living situation on the one side and the discovery that, together with these friends we associated with, we have the same vision (Male resident, Sülzer Freunde).

The second way in which groups come together is through professional leadership. Here, there is no pre-existing group, but an individual with particular technical skills (e.g. an architect or someone from the building sector) and the desire to self-build (and usually with a specific site in mind) advertises for others to join a group-build project. As one might suspect, the social motive is weaker or non-existent and the primary driver under this 'professional' model is reduced cost or the scope for customisation; building a home more suited to one's needs.

Yet the dividing line between these approaches can often be blurred as a result of particular group dynamics. It is not the case that all groups remain inward looking or that groups, once assembled, do not begin to believe in the primacy of the social motive. Even in the 'organic' groups, a key individual may act as a bridge to professional networks and thereby introduce extra-local resources and skills that may come to dominate the group and alter the relationships between founding members. Groups may, therefore, become de facto professionally-led. Similarly, those projects not incubated within an existing social network but led by a professional founder may take on some of the social and organic characteristics of the former. There is a degree of convergence between approaches as the projects progress and as stronger bonds form between individuals: new leaders emerge or the original leaders and initiators may come to take more of a back-seat. In the case of the Sülzer Freunde project, one prospective resident and an architect by trade acted as the key node, initiating group formation, dealing with the city planners and leading on the initial phase of the scheme. However, this individual subsequently handed management responsibilities over to an external facilitator once the development process began (Female resident, Sülzer Freunde). This resident facilitated the creation of the initial network and others - usually friends or relations of friends - were attracted to the group-build approach and joined because they were able to do so and bought into the initiator's vision. The network extended rapidly, drawing in relative strangers and also professional contacts able to see the project to completion. Ultimately, this was not merely a group of friends, but an extended network that bridged to additional skills as necessary, so as to deliver its vision.

The narrative at Vauban was rather different because a community organisation - the Forum Vauban - was instrumental in drawing residents' attention to the potential benefits of groupbuild. It was within that framework that a group of residents - all attracted to the idea of creating an environmentally sensitive scheme built to 'passive house' standards - came together, without professional initiation but in the context of an organisation actively promoting the idea and the benefits of group-build. At first, the social motive appeared absent. Members were drawn by the reductions in individual build and living costs that a combination of group-build 
and passive house construction offered. Yet ultimately, the sharing of resources and the support of others became important factors driving forward the process:

[...] first of all, one heard that it was cheaper because you only had to pay for the crane to come once; you only had to pay for the roofer to come once and do the whole roof in one go and this sort of thing and, secondly, just simply to have moral and real support from other people [was crucial] (Male resident, Vauban).

In both case study developments there was an implicit expectation that the experience of groupbuild would lead participants to become good neighbours. It was believed that the groups would continue to self-select through the various stages of the process, with only the sociable and likeminded remaining at the end of that process (Freiburg-based architect). Moreover,

You learn a lot about yourself and about your prospective neighbours, your future neighbours, during this whole planning period, which is much smoother, very beneficial if you buy from an investor, you buy a flat and you don't know the person who's moving in next door at all - it could be someone that you absolutely despise after six months. Within the self-building group, that's very difficult, because these difficulties will raise their heads much earlier (Male resident, Sülzer Freunde).

The opportunity for self-selection (and de-selection) was an important part of the social motive for group-build. In both case studies, participants believed that greater community cohesion would come from the collaborative nature of group-build from the outset. In reality, such enduring cohesion was found to form between households with similar educational backgrounds, similar values, and those occupying broadly the same socio-economic class. Wealth and income play some part in determining who can participate (Freiburg-based architect) even though only a modest capital outlay is required at the beginning of the process to cover start-up costs and professional fees. Participants must, however, also be able to access mortgage finance to cover total costs. Group-build was therefore found to attract a niche of residents whose financial means were strong enough to make them 'dependable' group members, but often who lacked the adequate financial resources to complete an individual self-build build project.

It became clear through the interviews that immediate or extended social networks played a key role in group-build schemes. Seen through a social capital lens, it was also apparent that reciprocities and trust (sharing resources and having the confidence to share liabilities) are an obvious outcome of group interaction. Broadly, the housing product emerges as a social good from the life of the group, being incubated by its supporting social network. We can observe in the social process, a coming together of like-minded people from similar socio-economic backgrounds, and the exclusion of those predicted to be 'bad neighbours' or unable to pull their financial weight through the delivery process (see next section). These aspects of the process point to clear social outcomes, which are explored further in the next two sections.

\subsection{The build phase and social processes}

Land acquisition is often the first major practical task for a group. In Germany, it has become usual practice for a municipal authority to sell public land to groups at a fixed price following design-based competitive bidding. Because groups are required to provide proof of project finances as part of their submission (Freiburg's former Director of Planning), this competitive approach is thought to improve design quality and ensure project delivery by filtering out financially weaker group members or group submissions. Some members therefore fall away at this stage. At Sülzer Freunde, one member left as they were unable to secure mortgage finance and other left as the scale of the project commitment became clear (Male resident, Sülzer Freunde).

After this initial 'reality check', the broader social group consolidates into a viable group for the project phase, sometimes with a clear leader emerging, depending on the complexity of the 
project ahead and the availability of technical skills within the group. In the Vauban case, a relatively small group of six households, and a comparatively straightforward task of constructing six terraced houses within a single-building structure, meant that no single leader or project manager was appointed from the group although the group member with the greatest experience of the processes emerged as a team-leader of sorts. The group relied on internal skills and the dedication of team members who contributed to the build process according to their experience. An externally-appointed architect managed detailed technical aspects of development whilst group members contributed in different ways, '[...] whether it was just keeping humour up at the meetings or practically' (Male resident, Vauban). However, the group's initial ad hoc arrangement became increasingly strained at weekly meetings during the build phase; and the absence of a formal management structure created space for tensions to surface between some members - the product of personality rather than major differences in opinion - although ultimately the 'energy' generated from inter-personal friction was harnessed to drive the project forward:

[...] my wife's particular strength is her determination at pushing through - and if there's something she didn't like, she just pushed through and actually Gabriella (at the end there) is the same kind of person and often they clashed, but on the other hand, due to this determination, we got it done (Male resident, Vauban).

Larger and more complex projects generate their own social and organisational tensions, centred on questions of leadership and power. Sometimes, an effective project manager was considered essential to the success of a scheme (Freiburg-based Architect). Although an apparently suitable candidate may emerge from the core group, it might not always be desirable to have an internal member playing such a pivotal role without an external and objective 'counterbalance'. For some larger projects, resident-led steering groups are formed to oversee legal matters and the construction phase (Freiburg-based Architect). At Sülzer Freunde, a significant challenge was to match apartments to the needs of specific members whilst taking forward a coherent designscheme with common elements. A 'construction commission' was set up comprising a subgroup of prospective residents. This was tasked to mediate between group members and the architect and, ultimately, it oversaw the allocation of build costs between residents: with top-floor apartments costing 10\% more than middle apartments and ground-floor apartments costing $10 \%$ less.

This 'commission' comprised five residents; two further, similarly-constituted, commissions were established to handle legal issues and the planning of communal areas, covering the gardens and shared facilities including a garage, workshop and guest apartment. The requirement for these resident commissions was not envisaged at the beginning of the process but it quickly became apparent that sixteen individual households each negotiating for something slightly or significantly different ' $[. .$.$] would have raised the architect's cost almost infinitely' (Male resident,$ Sülzer Freunde). However, the need to resort to commissions and to delegate decisions created a number of tensions that were difficult to reconcile with the 'consensual' way in which some members expected the groups to operate. In some instances, majority views within the commissions prevailed, leading to tensions between the victors and losers. At other times, there was greater investment in reaching consensus and this was viewed as being very much in the 'spirit' of group-build:

I always thought of myself as being some kind of dictator and knew exactly what I wanted and what I didn't want [...] I had an opinion in the beginning, a very definite $[\ldots]$ but during the discussions, it was easy for me to see the other points of views, so I could accept it easily (Female resident, Sülzer Freunde).

This collaborative process, achieved through the commissions, obliged individuals to expose their sometimes entrenched positions to group scrutiny. Ultimately, it was impossible for individual demands to prevail without threatening the viability of an overall scheme, either because the building would no longer be buildable or because a disintegration of the group would cause the entire project to stall. An important feature of group-build is that project success is 
entirely dependent on being able to work through differences, hold the group together, and ensure that individual aspirations align (to a significant extent) with those of the group. This can be illustrated in very simple ways. For instance, floor plans need to vertically align so that bathrooms and kitchens share common plumbing and windows are not haphazardly scattered across the face of a building. Prospective residents have to reach very simple compromises in order for a building to function. These simple compromises can be difficult to achieve. In the case of Sülzer Freunde, broad compromises were achieved during 67 meetings over a three-year period and, outside of these meetings, group members worked continuously with the architect to achieve internal customisation that would not disrupt the overall design. Although the process was punctuated with moments of anger and genuine doubt, the group needed to keep an eye on the whole thing' and to work collectively towards the general outcome that everyone seemed to want (Female resident, Sülz̨er Freunde).

As well as being vexed by these issues of building design, participants in the Sülzer Freunde project encountered the unexpected problem of enclosed garden space. Because residents at the top of the building were to benefit from roof terraces, it was felt by others that larger private gardens should be allocated to ground-floor residents, thereby subtracting from the quantum of shared outside space. A garden commission was established. This tried to balance the allocation of private and communal space in different ways, but failed. As a last resort, the group turned to a landscape architect, who was asked to find a design solution that delivered a mix of privacy and shared access. Despite differences in opinion remaining, a compromise was found which provided a final illustration of how group-build can only succeed when collective goals prevail over personal preference. In both the smaller Vauban schemes and the larger schemes at Sülzer Freunde it was only through dialogue, grounded in the direct interest of all participants, that projects are realised.

\subsection{The social legacy}

Strong social relations are a feature of both the Freiburg and Cologne schemes. In the former case, where most residents were strangers before the project started, this does not mean that strong friendships now exist between all residents. However, the shared experience of groupbuilding was thought to have created new friendships and increased familiarity:

[...] you've been going to meetings once a week for the last two years, you've been arguing with them, you've fought, you've stood your ground, you've compromised [...] the neighbours [next door] are really our best friends, that's really great, and we knew them before, although we didn't know them very well, but during this phase of building we got to know them better of course and they've remained very good friends [...] The others in the group, we're not great friends, we don't go in and out of each other's houses the whole time, we greet each other in the street [...] (Male resident, Vauban)

At Vauban, other research has suggested markedly stronger social relations compared with other Freiburg neighbourhoods. Comparing Vauban with Rieselfeld (another new neighbourhood where Baugruppen schemes account for around 10\% of all homes) and Haslach (a 'traditional' neighbourhood with no group-build schemes) Hamiduddin and Daseking (2014) found that the strength of social relations, measured in terms of familiarity / sociability, corresponded closely to the mode of housing delivery (see Table 1). The evidence appears to support the contention that group-build can have a transformative effect on sociability.

\section{[Insert Table 2]}

In Cologne, the build process has served to strengthen and enrich pre-existing social relations despite the frictions that surfaced during the build phase. The extent and depth of mutual support is striking; from practical assistance in spreading collateral across all households at the outset to enabling financially weaker participants to raise a sufficient deposit for a mortgage, to social support during decision-making. One group-builder claimed that without the support of 
the group they would have been 'totally lost' in the bureaucratic complexity of the process whilst another member of the same group drew attention to the trust between individuals that emerges out of group-build. This is only tempered by the view that, across society at large, individual goals are often prioritised above social ones. Yet in that same context, the act of group-building provides important lessons in what can be achieved, for individuals as well as the wider group, through social action.

The social legacy therefore appears to have two dimensions. The first is a heightened and measurable level of familiarity in those places that have, at least in part, been delivered through group-build activity. The second is a shared experience of self-help, and an awareness of how collective problems are resolvable through the 'power' of social capital. The findings presented here provide admittedly anecdotal evidence of a social outcome and patterns of familiarity are only suggestive of a lasting legacy. Clearly, there is scope for further analysis of the links between the mode of housing production in different places and social consequences.

\subsection{Group Build as Intentional Community}

Are group-builders intentional communities? The factors underpinning group-build - cost, customisation or community - are discernable from the outset of a project and it is often the case that the community factor may not be the primary driver. However, through the collaborative process of group-build and through the processes of selection and de-selection, closer social ties may form, leading ultimately to an outcome that roughly corresponds with Sargisson's (2012) notion of an 'intentional community'. The Sülzer Freunde project displays many of the hallmarks of an intentional community scheme, being formed from a group of mutual friends who set out to deliberately live together, although additional residents were brought into the project later on. By contrast, the Freiburg group was formed from a more ad boc mix of friends and strangers who collectively had little in common, other than a desire to build homes. The Freiburg group was significantly less motivated by social objectives, and much more by practical and financial considerations: to save money rather than achieve 'social therapy' (Freiburg-based Architect). These underpinning motivations influence the subsequent development pathway. Less communitarian groups may be more inclined to opt for a greater degree of professional project-management and building work, where limited options are given by a managing architect in order to provide the simplest and quickest route to delivery. Conversely, both cases suggest that a greater social emphasis in 'organic' groups can mean that residents are more 'hands-on', with greater potential cost-savings (and also greater risk of cost escalation) but with intensive engagement required. The 'organic' and 'professionally-led' project pathways identified here are, however, generalisations. Both the Freiburg and Sülzer Freunde cases may be considered to be 'hybrid' schemes, which nevertheless suggest the existence of these two distinctive, if not discrete, approaches.

More generally, group-build communities across the case-study areas tend to display two common characteristics, regardless of development pathway pursued. The first is that residents tend to be well-educated and often engaged in professional, salaried, occupations. Although the desire to save on housing costs provides an important motivating factor for self-build generally (Brown, 2007), interviewees stressed repeatedly that group-build - as practised in Germany would not be appropriate for less well-off households. This is because of the initial collateral required alongside the necessary budgetary flexibility and the potential for project over-spend. There needs to be 'financial' trust between participants; no 'weak link' in the chain.

The second characteristic is that households typically comprise younger couples (30 to 45 years old) with dependents. As one interviewee noted:

[...] there are 31 adults and 28 children, so we have quite a lot of families with three kids, two kids and maybe further kids coming in (Male resident, Sülzer Freunde).

A similar profile was observed across the six households of the Vauban case. More broadly, 
Vauban has a higher average household size (at 2.95) than Freiburg as a whole (1.92) and a much lower proportion of residents aged over 65 (2.1\% compared with 16.9\%). Although the groupbuild approach may be attractive to a wide cross-section of society, in Freiburg the approach has been most popular with former students who have stayed in the city after graduation and are now raising young families.

\section{Conclusions}

Despite international interest in the peculiarities of the German housing market and the propensity of certain cities to engage in innovative urbanism, group-build remains a niche activity; albeit an activity that is gaining popularity and appears to be on an upward trajectory. It connects with many different agendas: the need to deliver high-quality housing at an affordable price; the desire to deliver interesting, liveable places that are structured around good public services; alignment with individual needs and preferences; and also the goal - shared by many households - to rebuild community through collective effort. The research on which this paper drew set out to better understand the group-build development process by deconstructing aspects of that process in two German case studies, aiming to examine in particular (a) social processes in group formation, (b) how those processes evolve during the progression of a scheme, (c) the social legacy, and (d) whether or not group-builders can be conceptualized as (or eventually become) intentional communities.

Addressing the first issue (a), this paper has identified two main approaches to Baugruppen formation, which align with different motivations. However, the limitations of this simple binary framework have been acknowledged. 'Organically' formed groups may recruit additional members through formal processes and evolve into more professionally-led bodies in order to deliver their objectives. On the other hand, those groups that are brought together by built environment professionals may later take on many of the qualities of self-selecting social groups. During the evolution of projects (the paper's second theme (b)), the ongoing processes of selection and de-selection deliver two social outcomes: selective (or 'exclusive') community building (as those not entirely wedded to the project, or who do not fit in, fall away) and gentrification (as those unable ultimately to participate are lost; although many do not join in the first place). Group-build projects can be intense social experiences, which confront individual preferences with collective needs. Such confrontation can sometimes be dealt with through dialogue; in larger and more complex projects it requires careful mediation. The confrontations can result in a strengthening of the social group, but they can also result in a fragmentation and loss of members. Arguably, this might lead to a whittling down of the group and the formation of cliques, although evidence presented on broader patterns of familiarity (Hamiduddin and Daseking, 2014) in areas where group-build has been significant suggests social outcomes that extend beyond individual group-built developments. Indeed, in relation to the third theme (c), there is general evidence of greater familiarity and sociability (knowing and greeting neighbours) in residential quarters where group-build has been important. How this translates into higher and sustained levels of social capital remains largely unknown although with one significant project under their belts, it might be expected that local groups are better equipped to confront new challenges: because they understand the potential that exists locally and recognise the likely individual and social benefits of collective action. Lastly (d), although group-build housing projects do not generally equate with the 'intentional communities' that co-housing schemes aspire to, they can nevertheless deliver a number of comparable social outcomes. This is partly because these projects appeal to younger households who may be more ready to embrace aspects of communal living (Brinkley, 2013; Tummers, 2015). However, many of the physical signifiers of intentional communities - communal spaces and shared facilities such as common dining rooms - are usually absent from group-build schemes. That said, the environment generated by group-build - of familial trust built on common experience - seems to be attractive to households with young children or those who intend to start a family. In Germany, households expect to purchase a house only once - or a small number of times - in a lifetime and homeownership tends to be linked to raising children (Voigtländer, 2009). In that broader cultural context, group-build has particular appeal. The evidence from this study indicates that group- 
build - with its potential social drivers and outcomes - is seen by many to represent a familyfriendly and sociable model of housing production, characterised by strengthened social bonds and embodying one of the key ideals of an intentional community: the desire, at the outset or eventually, to pool resources and enjoy the fruits of collective responsibility measured in terms of increased social capital.

Are there broader lessons to be drawn from this study? Even in countries with a seemingly entrenched reliance on volume production (including the UK; Wallace et al, 2013), demand for self-build is exceeding the supply of opportunity. More supportive planning could play a part in increasing this opportunity, promoting 'group build' as one of a raft of alternatives to volume production. In the aftermath of the global financial crisis, the need for mixed-mode housing production (and therefore a system of supply with greater flexibility and durability) was an argument commonly presented by those who opposed 'business as usual'. Although business as usual seems now to be the direction of travel, it is clear that the benefits of self-build for individual households can be extended by the group-build approach, with those benefits taking on a social dimension whilst also reaching a greater number of participants. But a key lesson from Germany - returning to the first point - is that a context must be provided in which the power of speculative providers (especially over the land market) is curtained and group-build is given a chance to flourish. Group-build in both of the case-study cities was promoted through effective municipal control of land, involving the freezing of land prices and disposal through a competitive bidding process. There was an effective mechanism for value-capture, which meant that value was not lost to landed interests, but rather a part of that value could be retained for infrastructure upgrading whilst another part was effectively passed to the group-builders, who won the right development not only because of the price bid for their plot but also the quality of their proposal. Control of land enabled a transformation in expectation; development proposals judged not only against value for money criteria but also on the basis of good urbanism. If similar group-build models can be formulated elsewhere and embedded with new approaches to land value-capture then the potential benefits are manifold: from greater affordability through enhanced liveability, within and outside the home, to a lasting community legacy. Put simply, group-build can make a significant contribution to delivering better places. However, the German experience also points to potential pitfalls: there is a real risk, through community selfselection, of group-build becoming an exclusionary path to housing delivery. Although it is a niche means of production with potential for expansion, it cannot deliver against the needs of all households. Maximum benefit will be derived from this model if it is seen as one route to delivering the homes that communities need amongst a jigsaw of alternatives.

\section{Acknowledgement}

This research was supported through a UCL Grand Challenges award. We are grateful for that and also for the assistance provided by John Kelsey, Bartlett School of Construction and Project Management, at earlier stages of the project, and to the reviewers for their comments on earlier versions of the manuscript.

\section{References}

Bachelard, G. (1994) The Poetics of Space (Boston: Beacon).

Ball, M. (2005) European Housing Review (London: RICS).

Barlow, J., Jackson, R., \& Meikle, J. (2001) Homes to DIY for: The UK's Self-build Housing Market in the Twenty-first Century (York: Joseph Rowntree Foundation).

Bell, C. and Newby, H. (1976) Community Studies: An Introduction to the Sociology of Local Community (London: Allen and Unwin).

Bentzien, V., Rottke, N., and Zietz, J. (2012) Affordability and Germany's low homeownership rate, International Journal of Housing Markets and Analysis, 5 (3), pp. 289 - 312.

Boehm, T. P., and Schlottmann, A. M. (2014) The dynamics of housing tenure choice: Lessons from Germany and the United States, Journal of Housing Economics, 25, pp. 1-19. 
Brown, R. (2007) Identity and narrativity in homes made by amateurs, Home Cultures, 4 (3), pp. $261-285$.

Brown, S., Cerulli, C., Stevenson, F., Ash, C., and Birkbeck, D. (2013) Motivating Collective Custom Build (Sheffield: The University of Sheffield School of Architecture).

Brinkley, M. (2013) How Does Self Build in the UK Compare to Germany? Available at: http://www.houseplanninghelp.com/hph019-how-does-self-build-in-the-uk-compare-togermany-with-mark-brinkley-author-of-the-housebuilders-bible (accessed 25 July 2014).

Cerulli, C., and Field, M. (2011). Deconstructing the UK's housing speculation: finding a blueprint for a greener future in models of 'mutual housing', Long Term Economic Issues Seminar Birmingham, UK.

Chaskin, R. J., Brown, P, Venkatesh, S. and Vidal, A. (2001) Building Community Capacity (New York: Aldine De Gruyter).

Clapham, D. (2005) The Meaning of Housing: A pathways approach (Bristol: Policy Press).

DCLG (2011) Laying the Foundations: a housing strategy for England (London: TSO).

DCLG (2012) National Planning Policy Framework (London: TSO).

Dotson, T. (2015) Trial-and-error urbanism: addressing obduracy, uncertainty and complexity in urban planning and design, Journal of Urbanism: International Research on Placemaking and Urban Sustainability, (ahead-of-print), pp. 1-18.

Droste, C. (2015). German co-housing: an opportunity for municipalities to foster socially inclusive urban development? Urban Research \& Practice, 8 (1), pp. 79-92.

Duncan, S., and Rowe, A. (1993) Self-provided housing: the first world's hidden housing arm. Urban Studies, 30 (8) pp. 1331-1354.

Falk, I. and Kilpatrick, S. (2000) What is social capital? A study of interaction in a rural community, Sociologia Ruralis, 40 (1) pp. 87-110.

Golland, A. (1996). Housing supply, profit and housing production: The case of the United Kingdom, the Netherlands and Germany, Netherlands Journal of Housing and the Built Environment, 11 (1) pp. 5-30.

Hall, P. (2014) Good Cities, Better Lives: How Europe Rediscovered the Lost Art of Urbanism (Abingdon: Routledge).

Hamiduddin, I. (2015). Social sustainability, residential design and demographic balance: neighbourhood planning strategies in Freiburg, Germany, Town Planning Review, 86 (1), pp. 2952.

Hamiduddin, I. and Daseking, W. (2014) Community-based planning in Freiburg, Germany: the case of Vauban. In: Gallent, N., and Ciaffi, D. (Eds.) Community action and planning: Contexts, drivers and outcomes (Bristol: Policy Press).

Heidegger, M. (1971) Poetry, Language, Thought (New York: Harper and Row).

King, P. (2004) Private Dwelling: Contemplating the Use of Housing (London: Routledge)

Lawrence, R. J. (1987) Housing, Dwellings and Homes: Design Theory, Research and Practice (Chichester: Wiley).

Lloyd, M. G., Peel, D. and Janssen-Jansen, L. B. (2015) Self-build in the UK and Netherlands: mainstreaming self-development to address housing shortages? Urban, Planning and Transport Research, 3 (1) pp. 19-31.

Marcus, C. C. (2006) House as a mirror of self: Exploring the deeper meaning of home (Lake Worth: Nicolas-Hays).

NaSBA (2012) Planning for custom build housing: a practice guide (Swindon: NaSBA)

NaSBA (2011) An action plan to promote the growth of self-build housing (Swindon: NaSBA)

NaSBA (2014) Case Studies: Sülzer Freunde Cologne. Available at: http://www.selfbuildportal.org.uk/case-studies (accessed 21 July 2014).

Parvin, A., Saxby, D., Cerulli, C. and Schneider, T. (2011) A Right To Build - The Next MassHousebuilding Industry (Sheffield: University of Sheffield School of Architecture)

Putnam, R. (2000) Bowling Alone: The Collapse and Revival of American Community (New York: Simon $\&$ Schuster).

Sage, D. (2012) A challenge to liberalism? The communitarianism of the Big Society and Blue Labour, Critical Social Policy, 32 (3) pp. 365-382.

Sargisson, L. (2012) Second-Wave Cohousing, Utopian Studies, 23 (1), pp. $28-56$.

Savage, M., Bagnall, G., and Longhurst, B. (2005) Globalization and Belonging (London: Sage) 
Tummers, L. (2015) Understanding co-housing from a planning perspective: why and how? Urban Research \& Practice, 8 (1) pp. 64-78.

Voigtländer, M. (2009) Why is the German homeownership rate so low? Housing Studies, 24 (3) pp. 355-372.

Wallace, A., Ford, J. and Quilgars, D. (2013) Build-it-yourself: Understanding the changing landscape of the UK self-build market (York: Centre for Housing Policy at the University of York).

Weber, M. (1956) Wirtschaft und Gesellschaft - Grundriß der Verstehenden Soziologie (Tübingen: Mohr).

Westerheide, P. (2012) Market Stability, Housing Finance and Homeownership in Germany, in: White, M. \& Dunse, N (Eds.) Challenges of the Housing Economy: An International Perspective, pp. 153-169 (Chichester: Wiley). 